\title{
PERANCANGAN APLIKASI SISTEM PENJUALAN AIR MINUM DALAM KEMASAN PADA PT. GAJAH ASRI RAYA
}

\author{
Lena Magdalena dan Triana Ramadani \\ STMIK CIC Cirebon
}

\begin{abstract}
Abstrak
Seiring dengan perkembangan zaman, kemajuan teknologi khususnya computer selalu berkembang dengan pesat. Diantaranya dalam hal kegiatan akuntansi yang pada saat ini sudah menggunakan komputer sebagai alat pengolah dan penyimpanan data PT. Gajah Asri Raya merupakan perusahaan manufaktur yang masih menerapakan sistem manual dalam proses pencatatan laporan penjualan. Pencatatan dan laporan akuntansi atas penjualannya masih dibuat secara manual, sehingga sering menimbulkan beberapa kendala seperti pembuatan laporan penjualan yang memakan waktu relatif lama akibatnya tidak dapat memenuhi kebutuhan informasi yang bersifat segera. Untuk meminimalisir kendala yang terjadi dari sistem manual yang telah dijalanakan oleh perusahaan, dalam jurnal kali ini proses manual tersebut, dikembangkan menjadi terkomputerisasi. Sistem ini diimplmentasikan dengan menggunakan bahasa pemrograman Visual Basic yang diharapkan dapat membantu dalam mengelola data pencatatan akuntansi atas penjualan yang lebih akurat, terstruktur, dan dapat menghemat waktu. Hasil implementasi sistem informasi penjualan berbasis komputer ini menunjukkan bahwa proses pencatatan akuntansi lebih cepat dan tepat dibandingkan dengan menggunakan metode manual yakni dengan mencatat pada buku catatan manual dan Microsoft Excel yang mempengaruhi kecepatan dalam pengambilan keputusan sepihak manajemen perusahaan.
\end{abstract}

Kata Kunci: Rancangan, Aplikasi, Sistem, Penjualan, Air Minum

\section{DESIGN OF PACKAGED DRINKING WATER SALES SYSTEM APPLICATION IN PT. GAJAH ASRI RAYA}

\begin{abstract}
Along with the development of the times, technological advances, especially computers are always growing rapidly. Among them in terms of accounting activities that are currently using the computer as a means of processing and storage of data. PT. Gajah Asri Raya is manufacturing company that still apply the manual system in process of recording sales reports. Record keeping and accounting reports over its sales still made manually, so it often raises some constraints such as the creation of a sales report takes relatively long time as a result can not meet the information needs of the nonprofit soon. To minimize the constraints that occur from manual system that have been run by the company, in the journal this time manual process were developed to become computerized. This system is implemented by using the Visual Basic programming language that are expected to assist in managing the accounting logging data on sale to make it more accurate, structured, and can save you time. The result of the implementation of computer-based sales information system indicates that the accounting process more quickly and precisely than by using a manual method: with notes notebook manuals and the Microsoft Excel affect the speed of decision making in the management of the company.
\end{abstract}

Keywords: Design, Sales, Information, System, drinking water

\section{Pendahuluan}

PT. Gajah Asri Raya memiliki perusahaan di bidang Air Minum Dalam Kemasan dengan merk dagang "Arlida". Perusahaan ini berdiri pada awal Februari tahun 2014 dan hingga saat ini memiliki total karyawan sebanyak 98 orang. Setiap harinya perusahaan ini memproduksi air mineral cup sebanyak sepuluh ribu dus, dan memproduksi air mineral botol sebanyak enam puluh dus tetapi untuk produksi air mineral botol tergantung dari permintaan pasar. Perusahaan ini didirikan oleh bapak H. Habib Arif dan perusahaan ini beralamat di Jl. Pangeran Cakrabuana Kecamatan Talun Kabupaten Cirebon.

Melihat banyak transaksi penjualan yang terjadi pada perusahaan ini sangat disayangkan karena PT. Gajah Asri Raya belum menggunakansi sistem komputerisasi hal ini menyebabkan lambatnya proses 
pembuatan laporan yang dibutuhkan pemilik sehingga tidak dapat memenuhi kebutuhan informasi yang bersifat segera dan juga lambatnya perkembangan perusahaan.

Berdasarkan uraian diatas dijelaskan bahwa perlunya suatu perusahaan menggunakan komputerisasi untuk mengelola data dan laporan perusahaan.

\section{Identifikasi Masalah}

1. Siklus pencatatan transaksi penjualan pada PT. Gajah Asri Raya masih menggunakan proses manual.

2. Proses pelaporan data transaksi penjualan oleh karyawan seringkali mangalami keterlambatan dikarenakan pencatatan yang masih menggunakan proses manual

3. Proses pendistribusian laporan perusahaan kepemilik perusahaan masih dilakukan secara manual.

4. Tidak dapat memenuhi kebutuhan informasi yang bersifat segera dikarenakan pemrosesan data yang ada masih secara manual.

5. Rentan mengalami kesalahan pencatatan dalam laporan yang diproses karena pencatatan masih dilakukan secara manual pada buku akuntansi.

\section{Batasan Masalah}

Dalam pembahasan kali ini penulis hanya membahas seputar proses penjualan air minum dalam kemasan serta pelaporan hasil penjualan pada PT. Gajah Asri Raya Raya.

\section{Tujuan}

Tujuan dari perancangan yang dilakukan oleh penulis adalah:

1. Merancang suatu sistem penjualan yang berbasis komputer secara sistematis, tepat, cepat dan akurat.

2. Dapat merancang aplikasi aplikasi yang dapat mengurangi kesalahan maupun ketidaktepatan pencatatan dan pelaporan data penjualan.

3. Mampu merancang sebuah aplikasi yang dapat membantu memudahkan pencatatan dan pelaporan penjualan pada PT. Gajah Asri Raya.

4. Merancang aplikasi yang dapat membantu dalam hal menghasilkan laporan penjualan air minum dalam kemasan yang lebih tepat dan akurat.

5. Membantu memberikan solusi dalam meningkatkan pengolahan data penjualan dalam perusahaan.

\section{Perancangan Sistem}

Perancangan sistem adalah suatu kegiatan membuat desain teknis berdasarkan kegiatan pada waktu proses analis (Sugianto, 2013)

\section{Sistem}

Sistem adalah kumpulan/group dari sub sistem/bagian/komponen apapun baik phisik ataupun non phisik yang saling berhubungan satu sama lain dan bekerja sama secara harmonis untuk mencapai satu tujuan tertentu (Susanto, 2013)

\section{Penjualan}

Penjualan adalah bagian dari promosi dan promosi adalah satu bagian dari keseluruhan sistem pemasaran (Thamrin, 2013)

\section{Sistem Penjualan}

Menurut West Churman, sebuah sistem dapat didefinisikan sebagai serangkaian komponen yang dikoordinasikan untuk mencapai serangkaian tujuan (Krismiaji, 2002)

\section{Air Minum}

Air minum adalah air yang melalui proses pengolahan atau pun tanpa proses pengolahan yang memenuhi syarat Kesehatan dan dapat langsung di minum (Keputusan Mentri Kesehatan, 2002)

\section{Analisa Dan Perancangan}


Flowchart Sistem Penjualan Pada Pt. Gajah Asri Raya

Flowchart dibuat untuk mempermudah dalam mendeskripsikan alur sistem penjualan yang sedang berjalan pada PT. Gajah Asri Raya

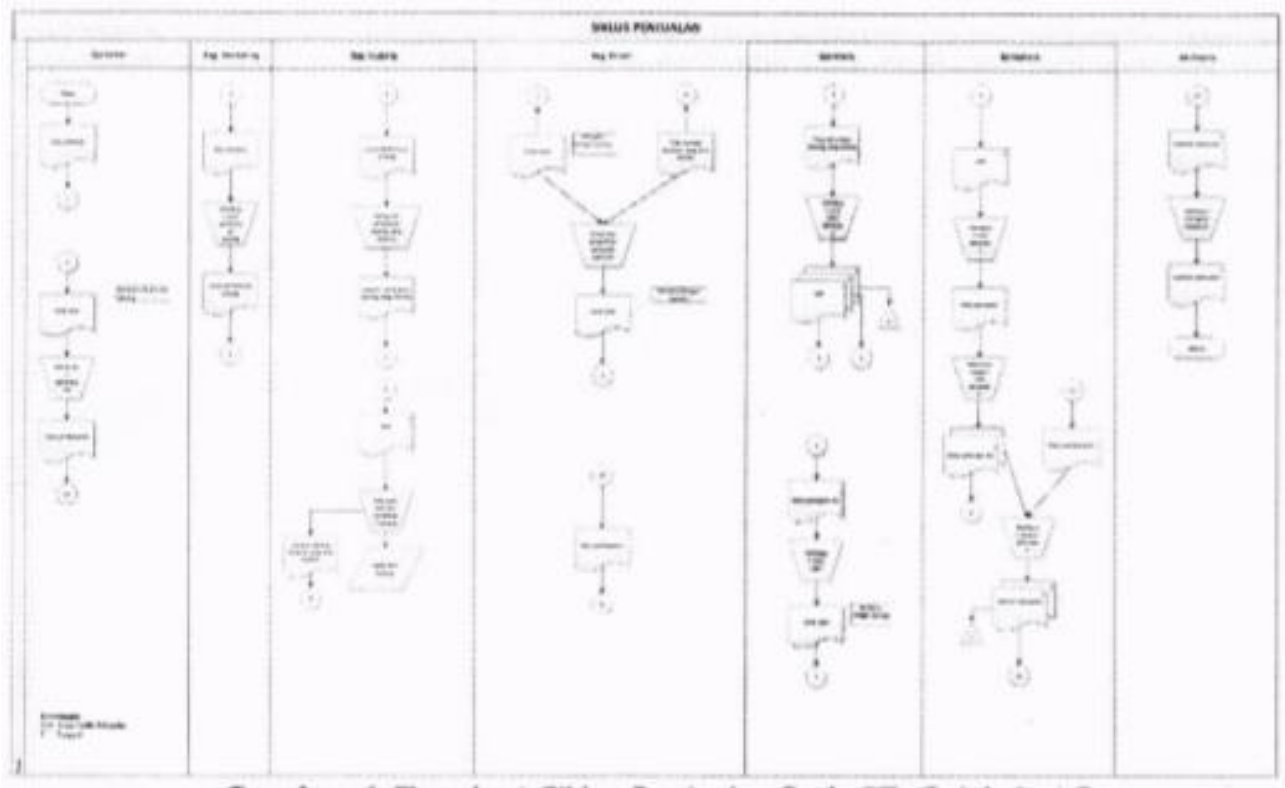

Gambar 1 Flowchart Siklus Penjualan Pada PT. Gajah Asri Raya

\section{Flowmap Sistem Penjualan Pada Pt. Gajah Asri Raya}

Flowmap dibuat untuk mempermudah dalam mendeskripsikan alur sistem penjualan yang di usulkan pada PT. Gajah Asri Raya.

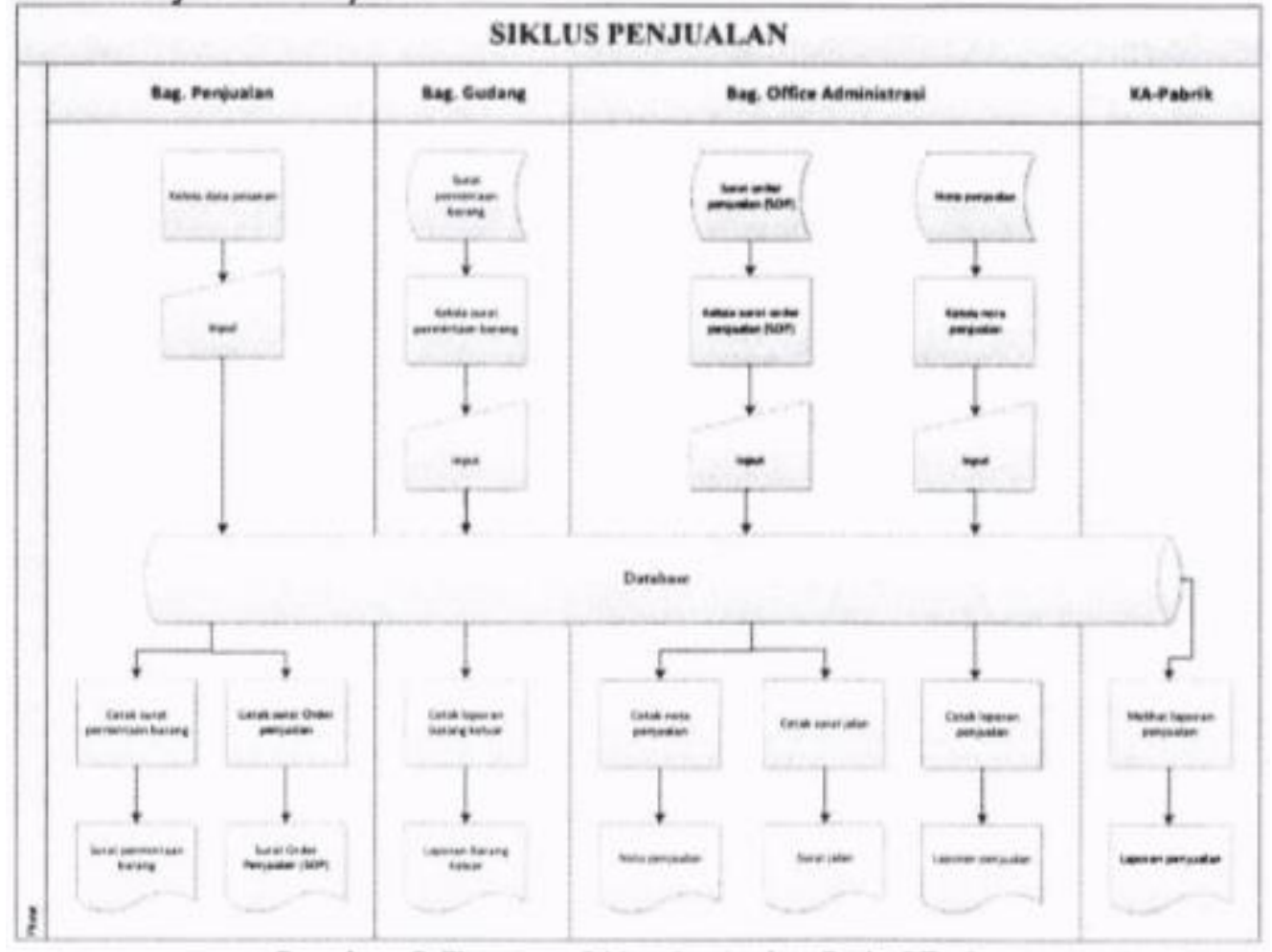

Gambar 2 Flowmap Siklus Penjualan Pada PT. Gajah Asri Raya

\section{Diagram Konteks}


Dalam suatu sistem akuntansi, Diagram konteks adalah gambaran prosedur secara global yang menjelaskan tentang aliran input, proses dan output data-data yang diolah. Diagram konteks untuk sistem penjualan di PT. Gajah Asri Raya dapat dilihat pada gambar 3 dibawah ini:

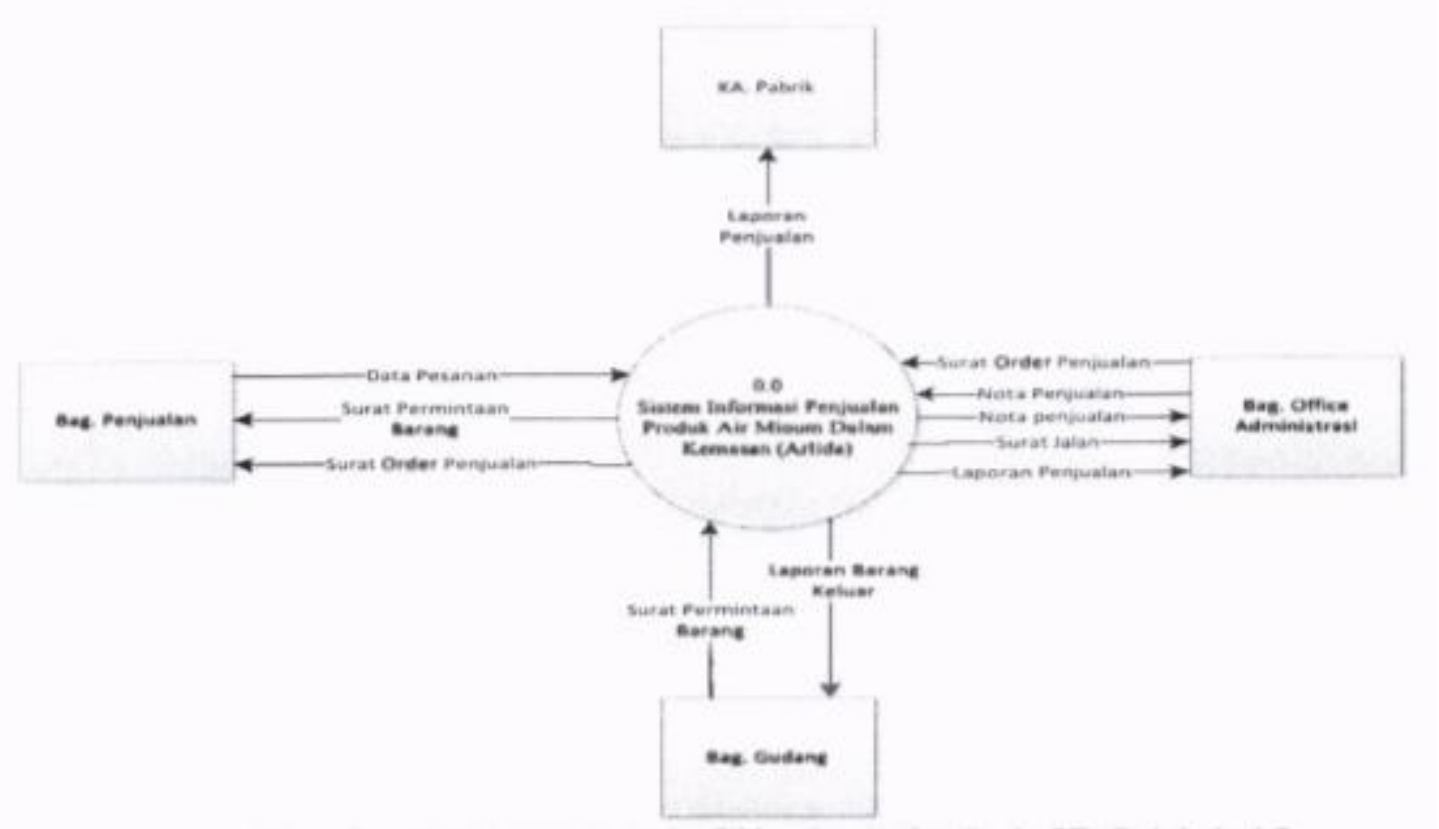

Gambar 3 Diagram Konteks Siklus Penjualan Pada PT. Gajah Asri Raya

Diagram Alir Data (Data Flow Diagram / DFD) Level-0

Data flow diagram merupakan gambaran sistem suatu jaringan proses fungsional yang dihubungkan satu sama lain dalam alur data, berikut merupakan gambaran sistem penjualan pada PT. Gajah Asri Raya: 


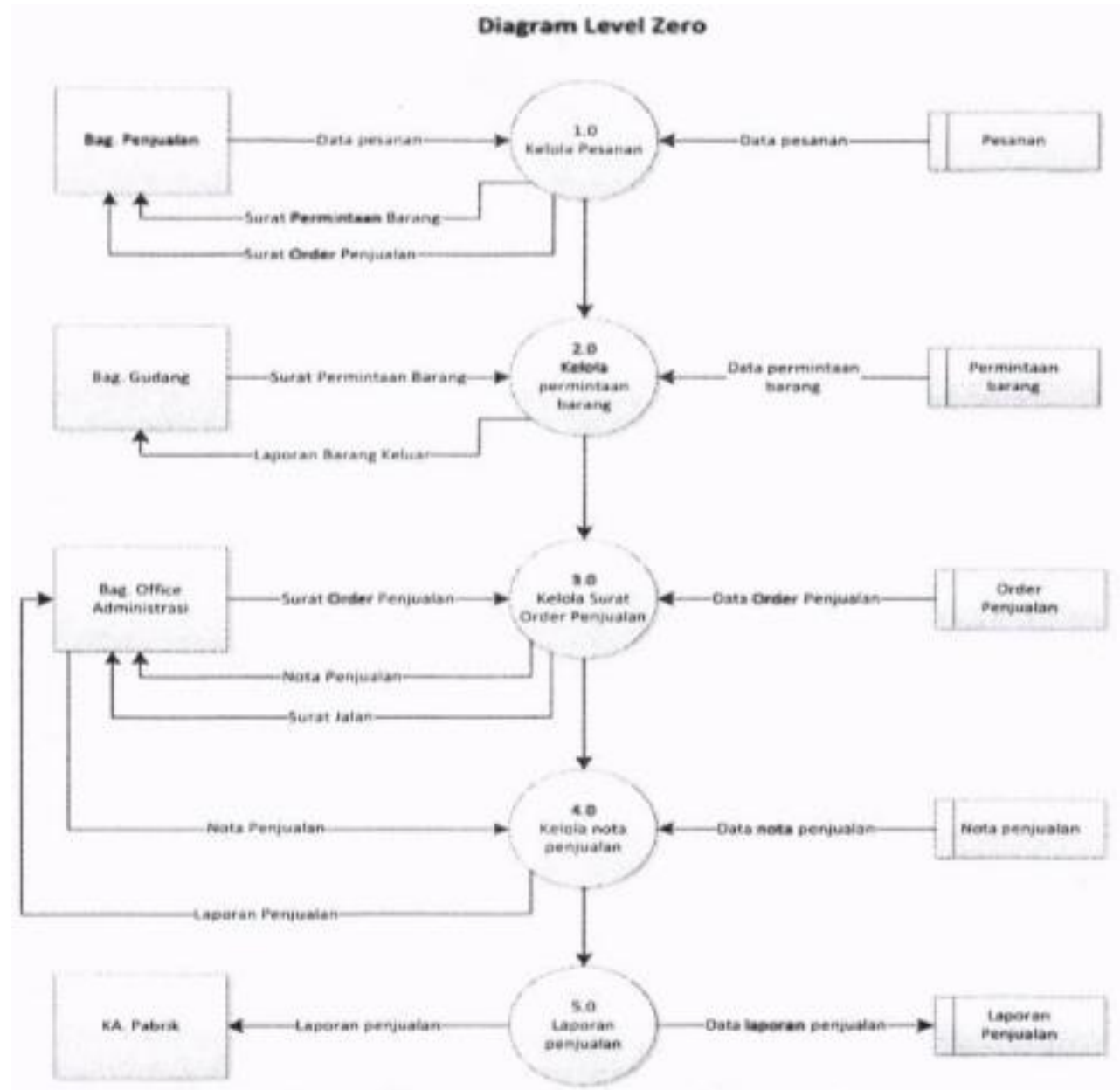

Gambar 4 DFD Level-o Siklus Penjualan Pada PT. Gajah Asri Raya

\section{Entity Relation Diagram}

Entity Relationship Diagram (ERD) merupakan rancangan umum sistem yang akan dibuat untuk mempermudah dalam pembuatan suatu database. Dibawah ini merupakan gambar rancangan ERD pada PT. Gajah Asri Raya: 


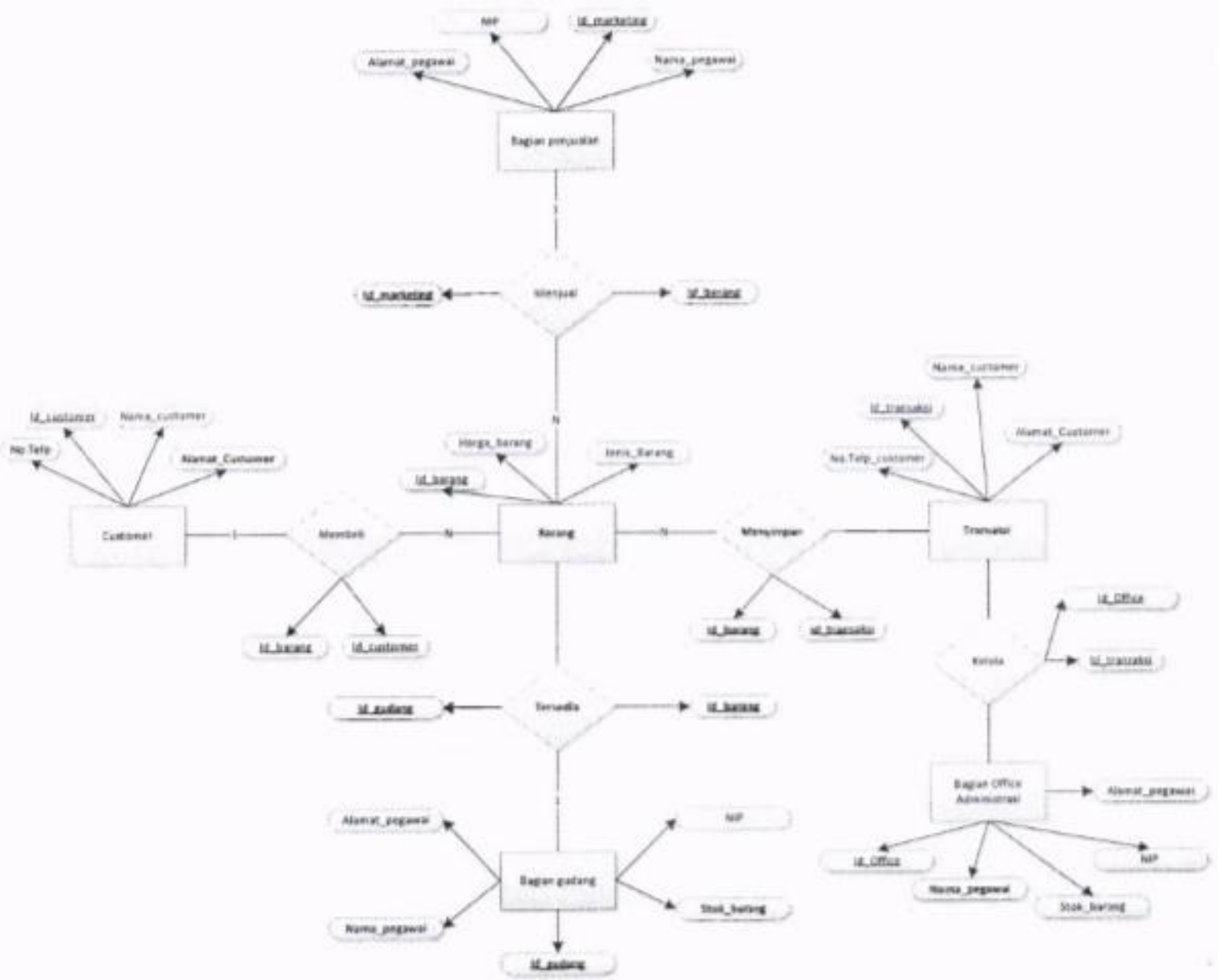

Gambar 5 Entity Relationship Diagram level-O Siklus Penjualan Pada PT. Gajah Asri Raya

\section{Tabel Relationship}

Tabel Relationship merupakan gambaran antar tabel yang saling terkait pada database. Keterkaitan tersebut ditunjukkan dengan penggambaran data-data penghubung yang menjadi primary key pada masingmasing tabel. Dibawah ini merupakan gambaran tabel relationship pada PT. Gajah Asri Raya:

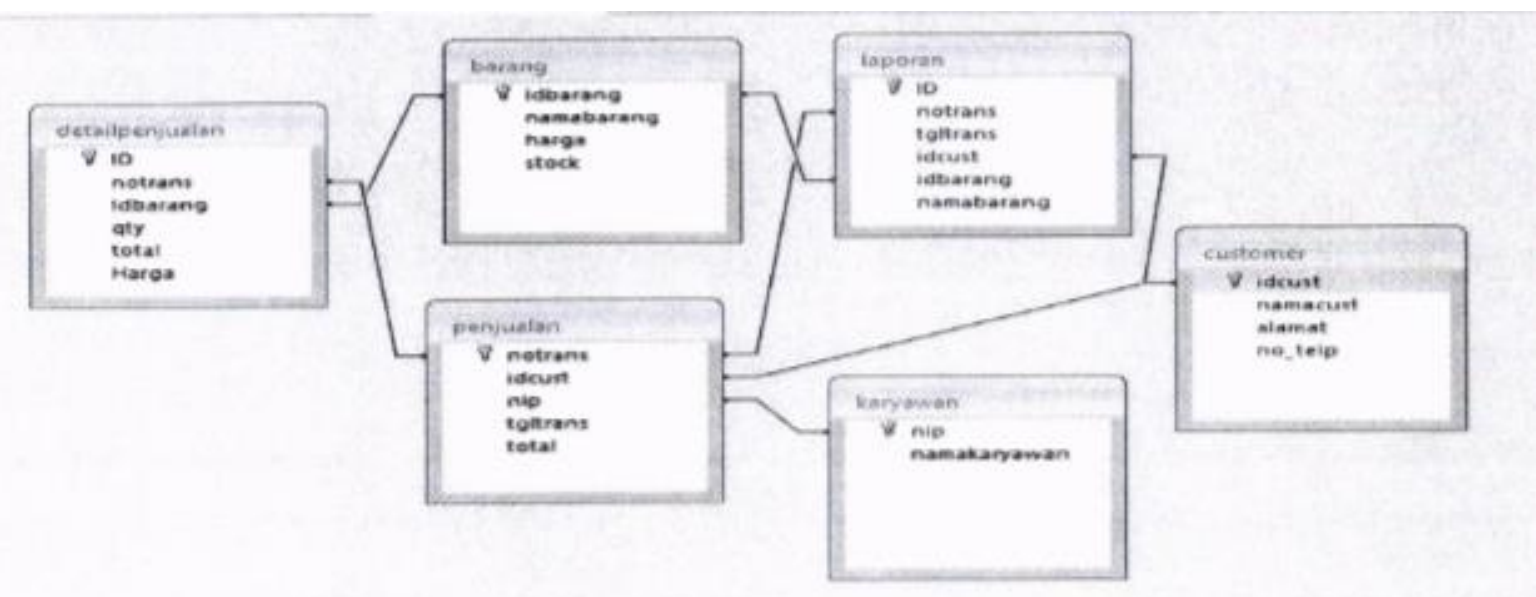

Gambar 6 Tabel Relationship Siklus Penjualan Pada PT. Gajah Asri Raya 


\section{Tabel Harga}

Pada perusahaan PT. Gajah Asri Raya melakukan proses produksinya setiap hari, kecuali hari minggu dan hari-hari besar lainnya. Pada perusahaan ini menerapkan dua sistem pembayaran upah yaitu pada bagian produksi menerima upah secara mingguan dan untuk kepala bagian divisi serta bagian office kantor menerima upah pembayaran setiap bulan. PT. Gajah Asri Raya setiap harinya mampu memproduksi air minum kemasan cup sebanyak 10.000 dus dan air minum kemasan botol sebanyak 60 dus. Berikut merupakan tabel harga dari produk yang dijual oleh PT. Gajah Asri Raya, harga berikut merupakan harga normal, apabila pembelian lebih dari 100 dus ada potongan harga dari perusahaan.

Tabel 1 Tabel Harga Barang Pada PT. Gajah Asri Raya

\begin{tabular}{|ccc|}
\hline No & Nama Barang & Harga \\
\hline 1 & Arlida Cup & 11.000 \\
\hline 2 & Arlida Botol & 21.000 \\
\hline
\end{tabular}

\section{Hasil Pembahasan \\ Form Login}

Dibawah ini merupakan rancangan form login untuk aplikasi penjualan, pada form login ini dapat di akses oleh tiga bagian dalam perusahaan, yang pertama adalah bagian penjualan yang akan memasukkan data costumer dan pesanannya ke dalam aplikasi. Yang kedua yaitu bagian office administrasi yang akan mengelola data penjualan yang di inputkan oleh bagian penjualan dan juga membuat laporan atas penjualan. Yang terakhir yaitu kepala pabrik yang akan mengakses aplikasi hanya untuk melihat laporan tidak untuk menginput data.

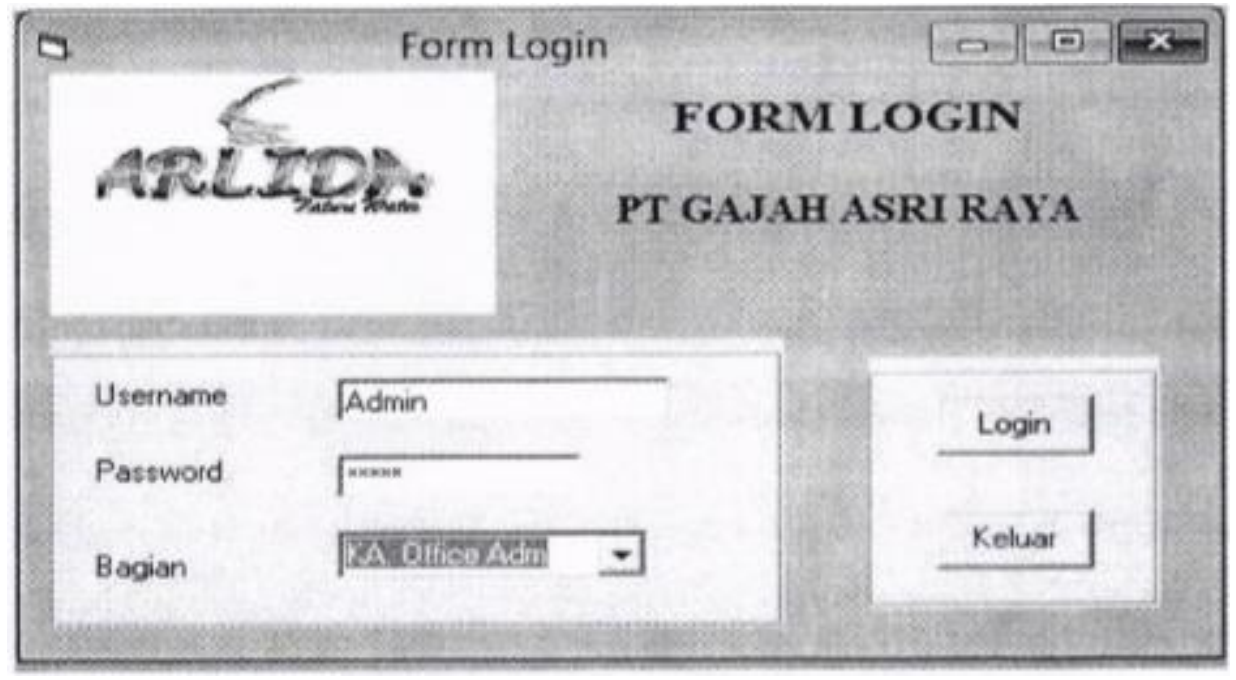

Gambar 7 Form Login Siklus Penjualan Pada PT. Gajah Asri Raya

\section{Form Menu}

Dibawah ini adalah form menu utama dalam aplikasi, yang terdiri dari menu transaksi menu ini terdiri dari sub menu barang, penjualan, dan customer. Kemudian ada menu laporan yang memiliki submenu laporan penjualan. Dan yang terakhir adalah menu logout untuk keluar dari aplikasi tersebut. 


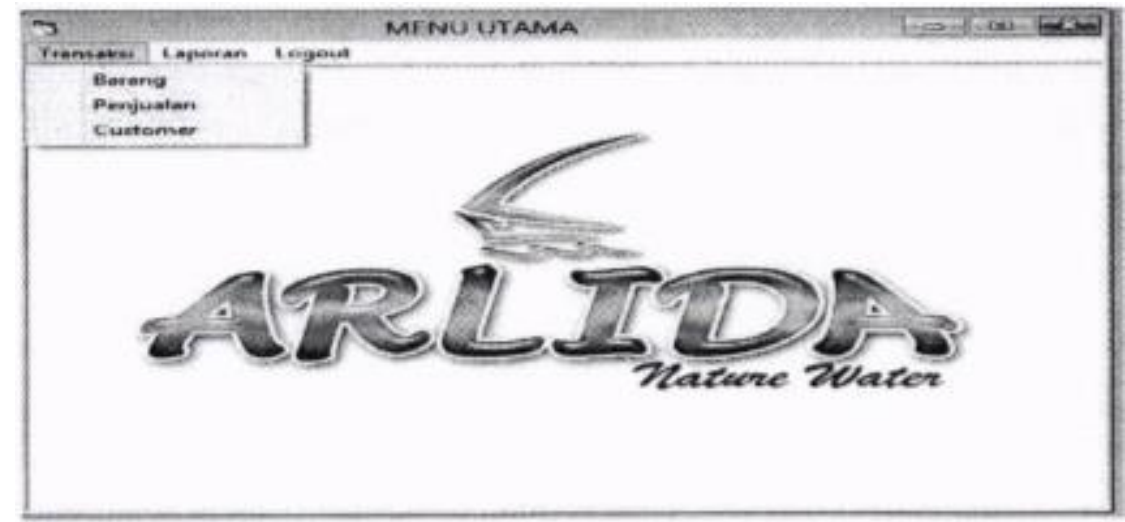

Gambar 8 Form Menu-1 Siklus Penjualan Pada PT. Gajah Asri Raya

\section{Form Barang}

Dibawah ini merupakan rancangan dari form barang yang digunakan untuk menambah daftar produk, mengedit daftar produk, dan juga menginput dan mengupgrade stok barang yang ada di perusahaan.

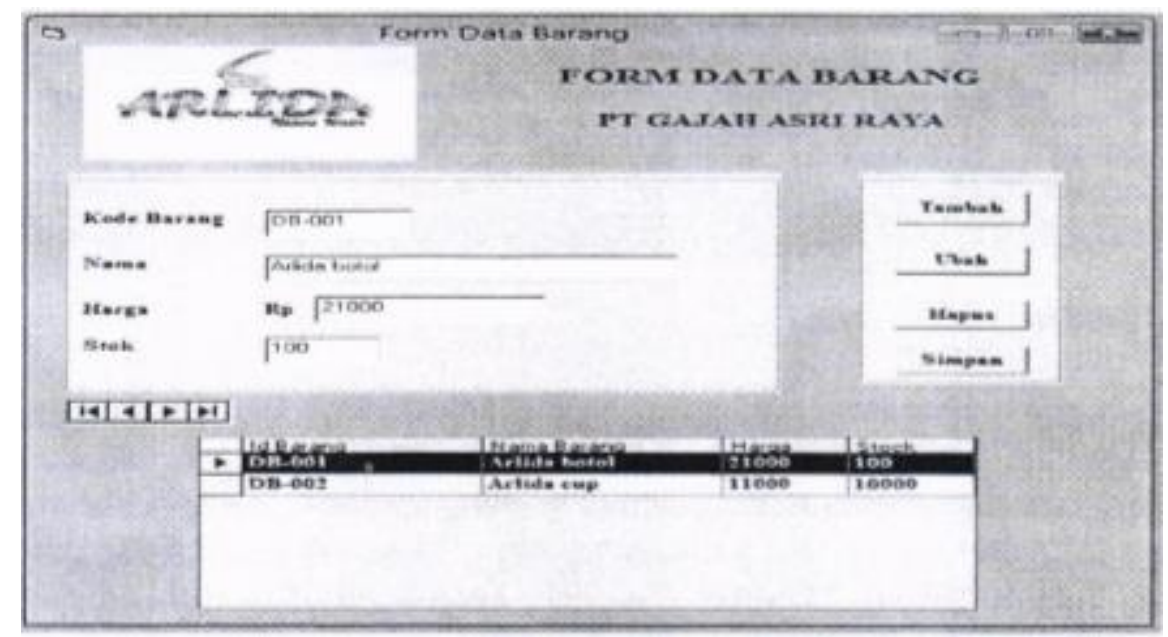

Gambar 10 Form Barang Siklus Penjualan Pada PT. Gajah Asri Raya

\section{Form Customer}

Dibawah ini merupakan rancangan form costumer yang digunakan untuk menginput, mengedit, dan menghapus data customer perusahaan.

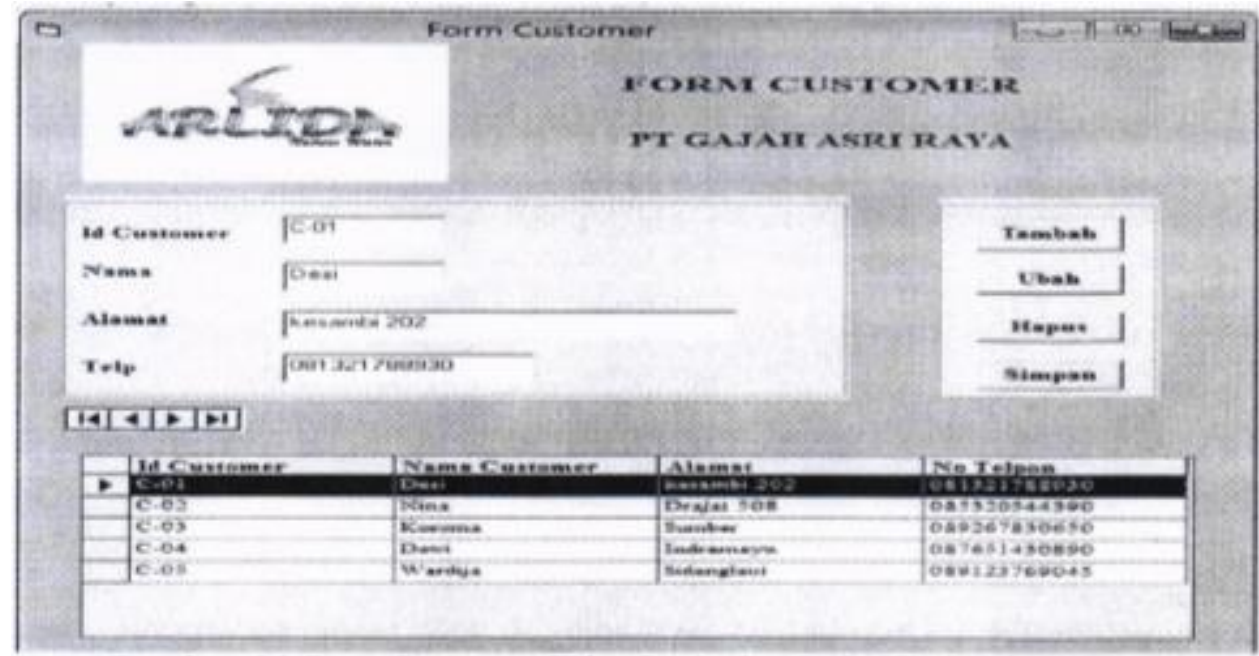

Gambar 11 Form Customer Siklus Penjualan Pada PT. Gajah Asri Raya 


\section{Form Master Penjualan}

Dibawah ini merupakan rancangan form master penjualan yang digunakan untuk mencatat transaksi penjualan secara garis besarnya saja, seperti nomor transaksinya, id customer yang melakukan pembelian barang, NIP pegawai yang melayani transaksi, tanggal transaksi dan juga total harga

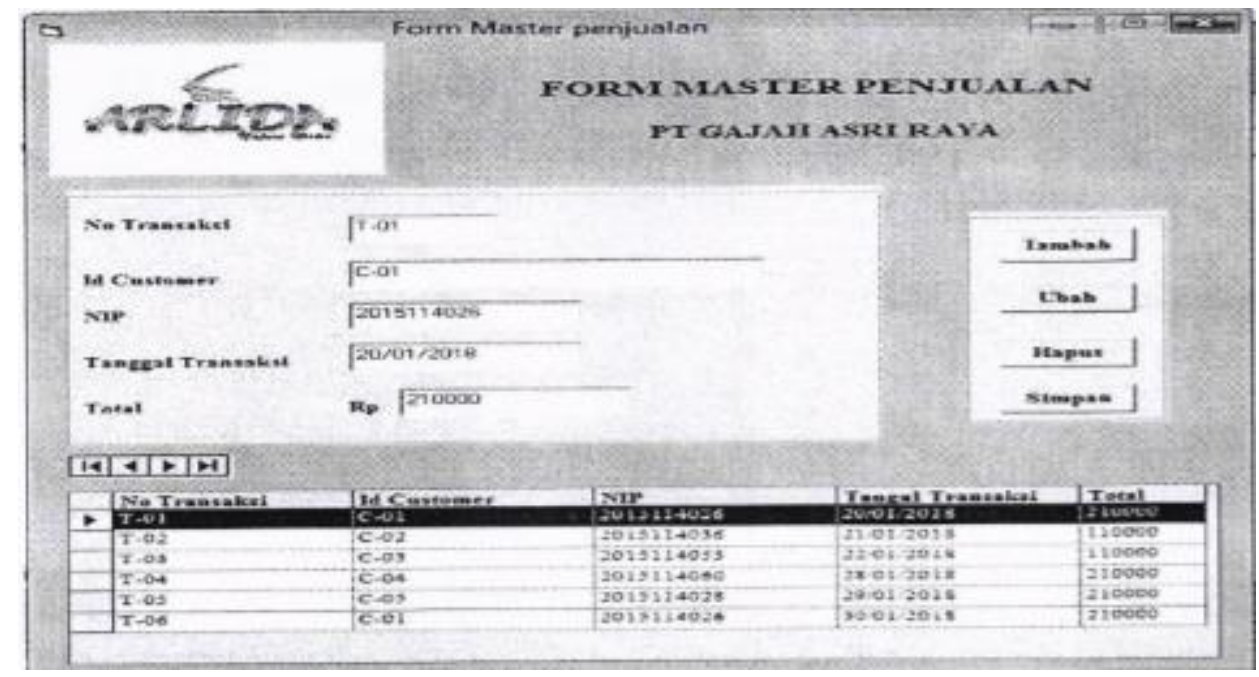

Gambar 12 Form Master Penjualan Siklus Penjualan Pada PT. Gajah Asri Raya

\section{Form Detail Penjualan}

Dibawah ini merupakan rancangan form detail penjualan yang digunakan untuk mencatat detail dari transaksi penjual yang terjadi, seperti id detail dari master penjualan yang ada, no transaksi, id barang yang dipesan oleh customer, banyaknya barang yang dipesan, harga satuan barang per dus, dan juga subtotal dari transaksi yang terjadi.

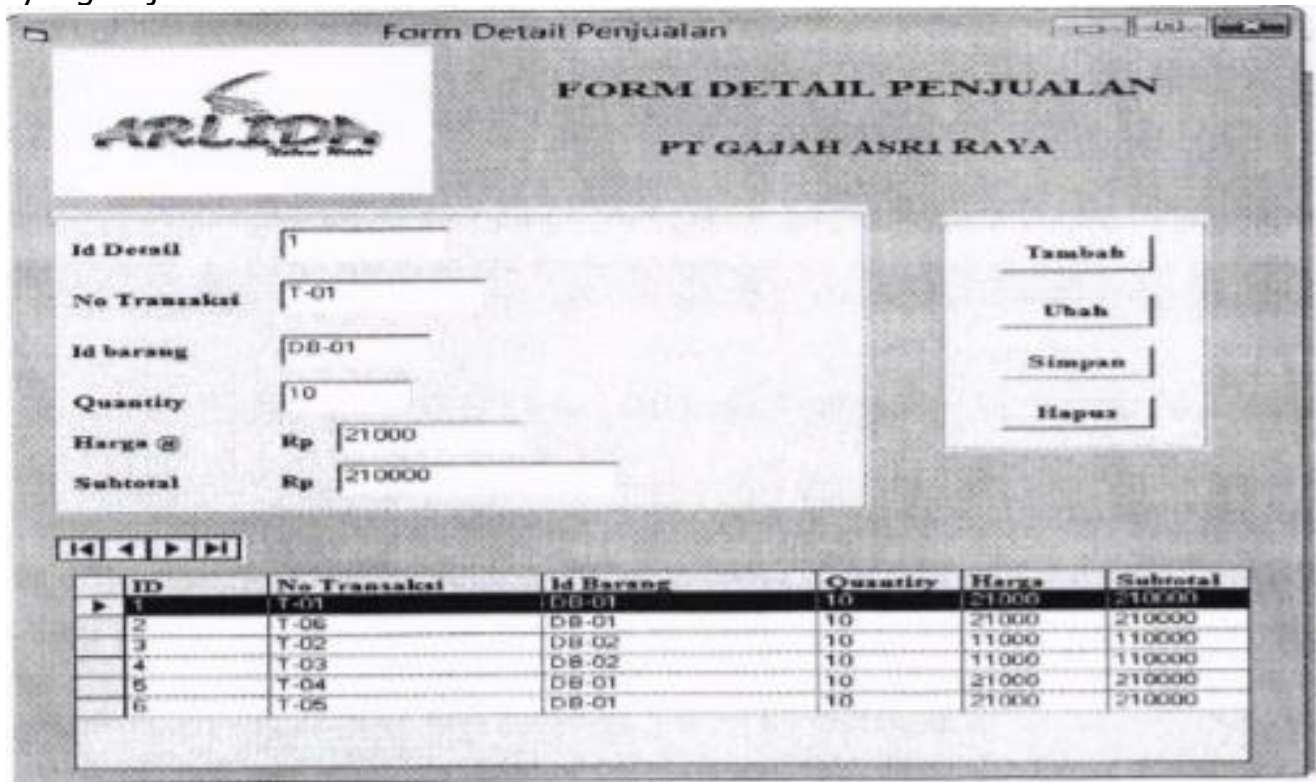

Gambar 13 Form Detail Penjualan Pada PT. Gajah Asri Raya

\section{Form Laporan Penjualan}

Dibawah ini merupakan rancangan form laporan penjualan yang digunakan untuk melihat periode laporan dan rekap transaksi penjualan yang terjadi. 


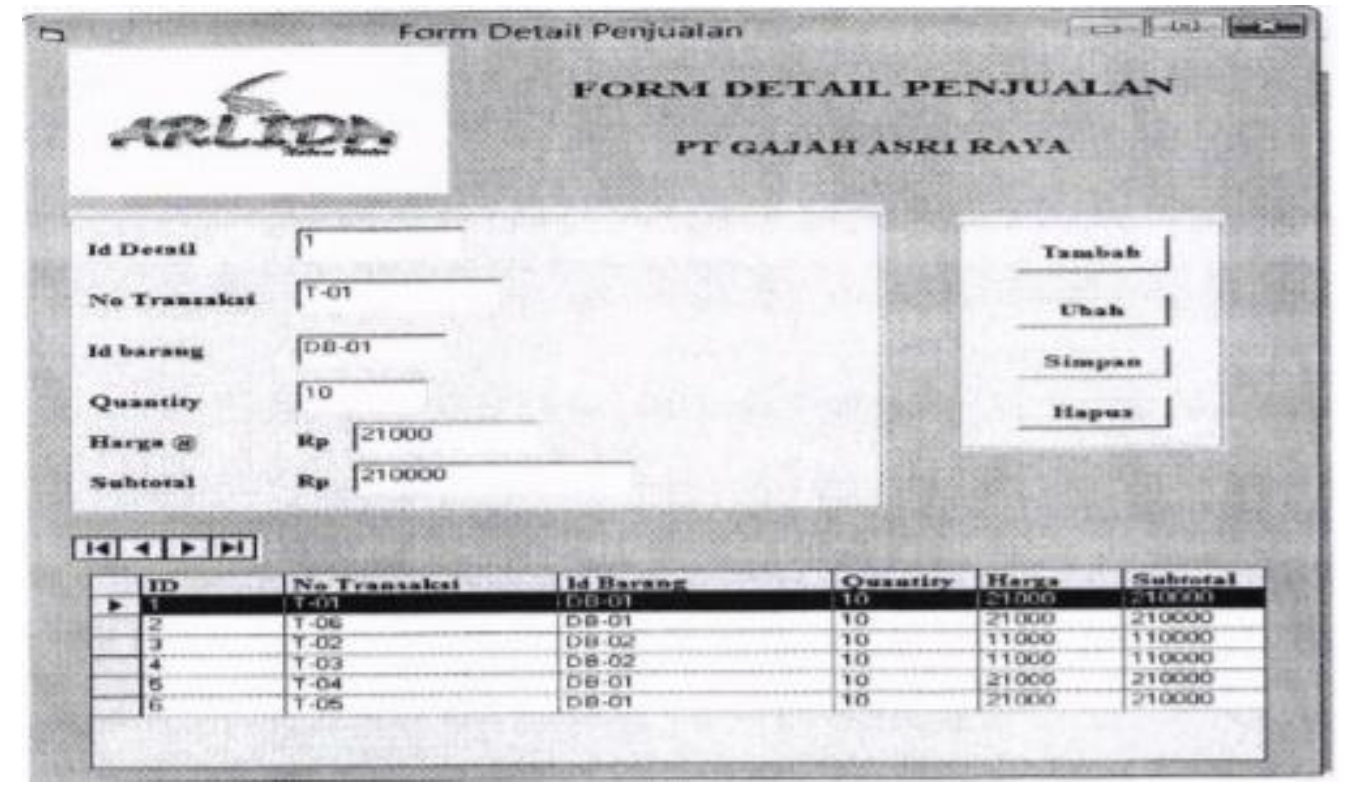

Gambar 14 Form Laporan Penjualan Siklus Penjualan Pada PT. Gajah Asri Raya

\section{Kesimpulan Dan Saran \\ Kesimpulan}

Dari hasil pembahasan tentang Rancangan Aplikasi Sistem Penjualan Air Minum Dalam Kemasan pada PT. Gajah Asri Raya, maka terdapat beberapa kesimpulan:

1. Telah dibuat rancangan aplikasi sistem penjualan komputerisasi berbasis Visual Basic 6.0. yang bertujuan untuk mempermudah pencatatan akuntansi penjualan serta pembuatan laporan penjualan pada PT. Gajah Asri Raya. Hasil keluaran dari rancangan aplikasi yang telah dibuat berupa: Rancangan nota penjualan, Rancangan surat jalan, Rancangan laporan barang keluar, Rancangan surat order penjualan dan Rancangan laporan penjualan

2. Dengan adanya rancangan aplikasi ini, maka diharapkan pihak perusahaan dapat lebih mudah dalam melakukan pencatatan dan menyajikan informasi tentang laporan penjualan air minum dalam kemasan.

3. Dapat mempermudah pendistribusian data dan laporan penjualan perusahaan kepada kepala pabrik (pemilik) serta lebih efisien terhadap waktu.

\section{Saran}

Untuk pengembangan lebih lanjut maka penulis memberikan saran yang dapat membantu perusahaan

PT. Gajah Asri Raya untuk masa yang akan datang yaitu:

a. Rancangan aplikasi ini belum sampai pada tahap implementasi, maka untuk pengembangan selanjutnya perlu dibuat basis data yang lebih sempurna untuk melengkapi sistem informasi ini.

b. Untuk masa yang akan datang baiknya dapat dilakukan pengembangan dan perbaikan secara berkesinambungan terhadap rancangan aplikasi agar lebih baik lagi dan sesuai dengan teknologi yang sedang berkembang pada masanya.

c. Untuk mengoptimalkan penggunaan aplikasi komputer ini, dianjurkan untuk melatih dan membimbing pegawai yang bertugas sebagai operator komputer (User).

\section{Referensi}

1. Sugianto, "Metode Penelitian Manajemen", Alphabet, Bandung, 2013

2. Susanto, Azhar, "Sistem Informasi Akuntansi", Linggajaya, Bandung, 2013

3. Thamrin, Abdullah dan Francis, Tantri, "Manajemen Pemasaran Depok", 2016

4. Krismiaji, "Sistem Informasi Akuntansi", Unit dan Percetakan AMP YPKN, Yogyakarta, 2002

5. Keputusan Menteri Kesehatan Nomor: 907 Tahun 2002 